about how public engagement factors into tenure and promotion decisions within institutions and departments. She notes the report has been delayed by the pandemic, but the committee will continue work on the report. S. Smith notes that this topic is of great interest in peer associations.

Linn, chair of the Conference and Meetings Policy Committee, reports that the committee has no updates to provide.

Julia Jordan-Zachery, chair of the Teaching and Learning Policy Committee, provides updates on the work of the committee. She reports that the committee is currently considering three topics: first, the committee is discussing support for contingent faculty through membership fees and access to eJobs as the market changes during and as a result of the pandemic; next, the committee is discussing how to offer support for online teaching, including drawing on the expertise of community colleges in online teaching; finally, the committee is discussing issues of diversity, equity, and inclusion. She notes the committee is considering creating a subcommittee or annual meeting panel to address the topics of diversity, equity, and inclusion.

\section{VOTE ON BUDGET}

S. Smith introduces the three-month budget for October 1, 2020-December 31, 2020 for Council approval. Linn moves to approve the proposed budget; the motion is seconded and passes unanimously.

\section{NEW BUSINESS}

S. Smith introduces discussion on the question of whether APSA should take a position on the scholars' strike, and, if so, what that position should be. S. Smith notes that the draft statement before Council was written by the three presidents: McClain, R. Smith, and Box-Steffensmeier. Sjoberg and R. Smith comment that the statement does not mention that a striker would not be penalized for abstaining from roles at the 2020 annual meeting on strike days. R. Smith adds that a sentence should be included about APSA respecting academic freedom and the civic commitments of scholars. Pepinsky asks if it would be prudent to include the specific reasons for the scholar strike, considering scholars may strike for various reasons, or if it would be more prudent to echo R. Smith's comment about respecting civic commitments of scholars in a general sense. Sjoberg moves to approve the statement conditional on amendment by the presidents to include language saying that APSA will not penalize scholars participating in the strike; the motion is seconded and passes unanimously.

McClain adjourns the meeting.

\title{
Minutes of the Winter 2020 Council Meeting
}

\section{DECEMBER 8, 2020}

PRESENT:

Janet Box-Steffensmeier, Ohio State University, President Paula McClain, Duke University, Past-President John Ishiyama, University of North Texas, President-Elect

Michelle Deardorff, University of Tennessee, Chattanooga, Vice President

Mala Htun, University of New Mexico, Vice President

John Sides, Vanderbilt University, Vice President

David Lublin, American University, Treasurer

Council Members: Ben Ansell, University of Oxford; Adam Berinsky, Massachusetts Institute of Technology; Erik Bleich, Middlebury College; Ann O'M. Bowman, Texas A\&M University; Menna Demessie, Congressional Black Caucus Foundation; Alexandra Filindra, University of Illinois at Chicago; Catherine Guisan, University of Minnesota; Rebecca Gill, University of Nevada, Las Vegas; Terri Gilmour, Midland College; Nancy Hirschmann, University of Pennsylvania; Nahomi Ichino, Emory University; Julia Jordan-Zachery, University of North Carolina at Charlotte; Sooyeon Kim, National University of Singapore; David Leal, University of Texas at Austin; Suzanna Linn, Pennsylvania State University; Lori Marso, Union College; Tamara Metz, Reed College; Ido Oren, University of Florida; Melanye Price, Prairie
View A\&M University; Jillian Schwedler, Hunter College; Alberto Simpser, Instituto Tecnológico Autónomo de México; Rocio Titiunik, Princeton University; Lisa Wedeen, University of Chicago.

APSA Staff: Steven Rathgeb Smith, Betsy Super, Dan Gibson, Kimberly Mealy, Nathaniel Bader, Larry Burner, Amanda Grigg, Jon Gurstelle, Casey Harrigan, Jessica Keefe, Abby Paulson, Ashley Vande Bunte, Clarissa Westphal Nogueira.

\section{INTRODUCTION}

APSA President Janet Box-Steffensmeier calls the 2020 APSA December Council Meeting to order.

\section{PRESIDENT'S REPORT}

Box-Steffensmeier reports on her plans for the coming year and notes that she has four priorities that she wants to help drive the work of the association in the next year. The first priority is methodological pluralism to ensure all political scientists are welcome. The second priority is a continuation of efforts to improve diversity, equity, and inclusion. The third priority is an emphasis on career diversity of political scientists in government, industry, nonprofits, and the academy. The final priority is supporting the advancement of democratic principles and public engagement. 


\section{FY 2021 BUDGET DISCUSSION}

Box-Steffensmeier opens discussion on the FY 2021 budget for Council consideration and approval. She reports that the Council voted in September 2020 to change APSA's fiscal year to correspond with the calendar year, so the Council has gathered to approve a new FY21 budget for January 1, 2021 -December 31,2021 . She emphasizes that there is uncertainty in the budget due to the effects of the pandemic. S. Smith notes that certain assumptions were made for budgeting purposes, including a $10 \%$ decline in membership, a smaller-than-usual annual meeting, and a reduction in rental income. He reports that APSA's investments have benefitted from significant gains in the stock market; however, APSA has projected conservatively due to ongoing uncertainty. He also notes that budgets in most programs have been reduced by $15-20 \%$, but the diversity and inclusion budget has increased to reflect new initiatives. Additional programming will also occur as a part of the Doctoral Dissertation Research Improvement Grants Program and the presidential task forces. Super notes that grants to support members were retained as budgetary reductions were focused on in-person programming. S. Smith notes that APSA should have more information shortly regarding insurance payments from the cancellation of the 2020 annual meeting. He reports that APSA received $\$ 450,000$ from the Payroll Protection Program (PPP), which is not included in the budget, and APSA is working to convert the PPP loan into a grant since APSA met the condition of not laying off staff. Lublin notes that APSA is well-positioned to weather the economic uncertainty. S. Smith notes that the Council will be consulted throughout the year on budgetary and financial matters. Linn moves to approve the FY21 budget; the motion is seconded and approved unanimously.

\section{DISCUSSION OF 2021 ANNUAL MEETING}

Vande Bunte introduces discussion of the 2021 annual meeting for Council consideration. She notes that APSA is running focus groups with division chairs, section chairs, and committee chairs and reports that APSA is currently planning on holding an in-person meeting but will continue to pay attention to and follow health and safety guidelines. She further notes that cancellation fees increase after March 1, 2021. APSA does have force majeure clauses in the contracts, but those clauses would not apply until closer to the annual meeting date. Vande Bunte and Suzanna Linn, chair of the Meetings and Conferences Policy Committee, note that there is a possibility of hosting a separate virtual event. Linn notes that virtual options are being discussed, including the possibility of a series of virtual events. She notes that an in-person event may only be able to be attended by those whose institutions can afford for them to travel. Ishiyama asks about the feasibility of a hybrid option. S. Smith notes that a hybrid option is being discussed, but that a hybrid model run simultaneously can make hybrid a high-cost and low-revenue event. He reports that Council will decide on a format in the next few months. Ansel mentions that with virtual or hybrid models, it is important for virtual attendees to be engaged in some manner with the panel or presentation. Bleich suggests the possibility of hosting both an in-person conference in the fall and then a virtual conference in the spring. Ishiyama asks about the status of room blocks and hotel contracts in Seattle. Vande Bunte replies that she is working with the hotels to negotiate reductions in the room blocks. Metz and Htun mention that virtual meetings reduce carbon footprints. Hirschmann suggests meeting in-person only every other year. S. Smith notes that APSA is booked through 2027. Super suggests that people may be less interested in virtual meetings once it is safe to do in-person meetings. Lublin notes that in-person meetings have value for networking, which is a major draw of the annual meeting. Ishiyama makes a motion for APSA to explore options for the annual meeting that consider hybrid models and a reduction in carbon footprint; the motion is seconded and passes unanimously.

\section{ETHICS ISSUES}

S. Smith updates the Council on a variety of policies and changes being developed to address issues of ethics, harassment, and sanctions. He notes that the 2015-2016 Council appointed an ad hoc committee to develop policies focusing on sexual harassment at the annual meeting and these recommendations were implemented in 2016-2017. S. Smith indicates that Council subsequently discussed policies regarding sexual harassment and professional misconduct outside of the annual meeting and appointed another ad hoc committee that has developed recommendations. These recommendations will be brought to Council after review by legal counsel. S. Smith notes that the ethics guide is also being reviewed and updated by the Committee on Professional Ethics, Rights, and Freedoms, and these revisions will be brought to Council once completed. Mealy notes that the Committee on Professional Ethics, Rights, and Freedoms has discussed whether APSA should take action in the case of sanctions brought against a member by another institution or organization and has considered issues including the need for due process and reporting and notification. Htun and Price ask how the association will be notified of other institutional findings. Mealy indicates that the committee has not yet resolved this question. She notes that peer associations are also working through this question. Gill indicates that a focus should be placed on making victims feel heard and safe. Kim asks what sanctions APSA may impose, and Box-Steffensmeier adds that the scope of a sanction is important to consider through this process. S. Smith notes that, according to the bylaws, Council can revoke membership for an individual and apply sanctions regarding the annual meeting; however, there is no clear policy for sanctions between these two examples. He indicates that the topic of further sanctions will be brought before Council. Htun notes that there are informal and non-codified procedures to address issues of harassment that have not reached the threshold of a formal sanction. Ishiyama asks when a comprehensive policy may be ready. Mealy replies that the goal is to have a draft ready for the spring Council meeting; however, this draft will also be circulated to the ethics committee, policy committees, and legal counsel. Htun and Gill note that this may not be a comprehensive policy, but it is a step in the right direction. Filindra asks where in APSA's structure are ethics complaints reported. Box-Steffensmeier and Mealy reply that complaints may be filed in multiple places but there is a formal reporting mechanism to address complaints. Council discusses the classification of sexual harassment under the broad framework of ethics and if that is the best place for these complaints to be heard. 


\section{TRANSFORMATIVE JOURNALS DISCUSSION}

Box-Steffensmeier introduces discussion of the transformative journals proposal for Council consideration. She reports that, in response to a call for the expansion of open access journals, Cambridge University Press asked APSA journals and some Organized Section journals to sign on to a Transformative Journals Agreement that would set a path for a transition to open access. She notes that the agreement is non-binding and has no signing deadline. Leal, chair of the Publications Policy Committee, notes that there is a great deal of uncertainty around open access. Journals generate large amounts of revenue for associations, though the revenue is smaller in the humanities and social sciences than in the physical sciences. Leal details the transformative journal proposal from Cambridge University Press. He notes that APSA would commit to increase open access articles by five percent each year until, once $75 \%$ open access is reached, the journal would become completely open access. Leal reports that about $17 \%$ of APSR articles are open access but this percentage is lower in other APSA and Section journals. Leal notes that long-term implications are unclear, but APSA will eventually lose access to articles about research supported by funders who are a part of this agreement. He raises a variety of questions, including the sustainability of an open access business model, where would non-funded research go, can authors afford this model, would libraries pay author publication fees, what if more US funders or the US government becomes more involved in open access, and will authors agree to new license agreements. Leal concludes his description of the proposal by noting that APSA can observe the open access movement, but that APSA does not know all the implications of the proposal.

Simpser raises a point on revenue sharing and notes that it seems that presses will continue to receive the same amount of revenue, but the burden of costs will be borne by authors or funders. Ansell notes that social science journals do not make large profits, but medical science journals are much more profitable. He suggests that the social sciences are caught between much larger powers. Ishiyama asks what Cambridge University Press is proposing to assist in defraying author publication costs. Gurstelle replies that only funded authors will have author publication costs defrayed. Ishiyama asks how the $75 \%$ open access will be determined. Gurstelle replies that Cambridge University Press has entered into an agreement with Plan $S$ that accounts for all Cambridge University Press journals collectively. Wedeen and Schwedler note that this proposal advantages authors that have large research budgets, are funded by grants, or that write articles with multiple coauthors. Berinsky and Ishiyama note that open access comes down to a question of who pays in the various funding models. Simpser asks if there can be an alternative funding model for the social sciences. Titiunik recommends that higher education institutions be consulted regarding the proposal. Price notes that the proposal will affect the discipline by building in and perpetuating inequities across universities and research subfields. She also emphasizes that publications affect ability to get tenure, and, if this proposal is adopted and inequities perpetuated, APSA may see more scholars unable to receive tenure because of an inability to get published. Lublin notes that the social sciences have minimal leverage in negotiating with Cambridge University Press, but APSA does not want a system where authors may have to pay hundreds or thousands of dollars to publish. The Council agrees that additional consid- eration and study is necessary.

\section{MEMBERSHIP INITIATIVES}

Harrigan introduces discussion of new membership initiatives for the purpose of updating Council. Harrigan reports that APSA is in the process of implementing a 90-day trail membership option that provides access to online journals and eJobs but not annual meeting member registration. She notes that this is a one-time only membership option that can introduce APSA membership to groups with lower rates of APSA membership, such as community college faculty and political scientists employed outside of academia.

S. Smith reports that member relief grants have been made available and there has been substantial demand. He notes that an appeal will go out to members to donate and replenish the relief grant funds. Lublin reports that he received some questions about the possibility of APSA temporarily reducing member dues to assist those who are struggling to pay dues because of the pandemic. He notes that various models exist, including but not limited reducing membership dues for all members or only for a subset of members. Bleich and Price support a temporary universal rate reduction to avoid assumptions about which members need relief. Bleich suggests the possibility of allowing members to pay the membership costs for a member who cannot afford to pay. Hirschmann notes that the economic ramifications of the pandemic may not be limited to a single year. She voices support for an extended sliding scale of membership costs and notes that research accounts, not just income, affect one's ability to pay member dues. Hirschmann asks about the possibility of using section funds to subsidize member dues. Harrigan replies sections can make grants available to their members but cannot directly subsidize member dues because the accounting would involve APSA directly paying APSA.

\section{UPDATES ON DEMOCRACY 2020 INITIATIVE}

Box-Steffensmeier introduces discussion of the Democracy 2020 initiative by celebrating and recognizing the work that went into the programming, events, teaching resources, and more. She notes that Council also authorized an election assistance task force, and Grigg reports that the task force created op-eds, held a student poll worker essay contest, highlighted political science research, and compiled teaching resources. Grigg notes that the Democracy 2020 initiative is now focused on the presidential transition. She indicates that she and others are working on how to build upon the framework and make parts of the initiative and task force more permanent, especially in non-election years. Box-Steffensmeier notes that this initiative may become a permanent committee.

\section{NEW BUSINESS}

Guisan introduces discussion of the importance of considering the needs of contingent faculty, particularly given that the number of contingent faculty may increase due to the effects of the pandemic. Box-Steffensmeier notes that only a small portion of the membership are employed outside of the academy, and that she would like to work to increase that portion of the membership. Demessie agrees and notes that there is a demand for political scientists in policy spaces.

Box-Steffensmeier adjourns the meeting. 